\title{
Sociology in Finnish Forest Research
}

\author{
by
}

R.A. Young'

\begin{abstract}
In Finland, where a high proportion of forested land is owned by smallholders and farmers, a sociological tradition of forest research has evolved. This paper reviews the landmark studies of forest owners and their behaviour.

In Canada, where much will be expected of private woodlot owners in the next two decades, this research deserves to be better known and to be emulated, because it is scientifically sound and highly practical.
\end{abstract}

\section{Résumé}

En Finlande, où une forte proportion des terres boisées appartiennent à de petits propriétaires et à des fermiers, on assiste à une évolution dans la tradition sociologique de la recherche forestière. Cet article résume les études de pointe effectuées relativement à ces propriétaires forestiers ainsi que leur façon d'agir.

Au Canada, où on attend beaucoup de la part des propriétaires forestiers dans les deux prochaines décennies, cette recherche mérite d'être mieux connue et sensibilisée, vu qu'elle est fortement scientifique et pratique.

\section{Introduction}

Finland's history is very different from Canada's, but this northern, forested country shares many characteristics with us. Doubtless, its semi-feudal, peripheral past, its civil war (of 1917), its later industrialization, its post-war experience as an uneasy neighbour of the U.S.S.R. - all set it apart, as do its contemporary corporate organization and political system. But Finland's latitude, terrain, forest species, (Norway spruce, Scotch pine, and white birch), and even the atmosphere of its lumber towns and the staunchly indepedent attitudes of its farmers are not unlike their Canadian counterparts.

The Canadian forester will notice, however, two striking differences: first, Finnish forests generally are more intensively managed; second, the Finnish industry is more dependent upon small, private forests for its wood supply than is the Canadian. This latter characteristic has given rise to a tradition of research which aims, concretely, to help smallholders improve forest management, and it is these studies with which this paper is concerned.

In Canada, as pressure on wood supplies increases, private forests, even smallholdings, acquire greater marginal importance. (Darveau, Grenier, Lussier, 1978; Senior Forestry Officials, 1979, p15). Finnish forestry laws and the organizations which promote private silviculture are unique, and are probably not transferrable. I would maintain, however, that the way of studying private forestry in Finland is quite applicable to Canada, and that we may benefit much from a tradition developed where the small woodlot is so important and so highly productive.

\section{Small-scale Forestry}

Waves of settlement in the 20th century have made the small farmer predominant in the Finnish countryside (Jones, 1977). When the rural population peaked, in 1969, there were 300,000 farms, with an average size of only 52 hectares, and with an average woodlot of 34 hectares

${ }^{1}$ D.Phil., Department of Political Science, McGill University
(Siuruainen, 1978). After independence, in 1917, landless labourers were settled: the country's economy was based on the forest industry and its exports, and it was fear of overcutting and devastation which led to the 1928 Law on Private Forests and also to the Forest Improvement Act. These measures forbade premature cutting and provided some funds for private silviculture (Holopainen, 1968; Marsh, 1954). During the 1930s, following the first close study of farm forests (Osara, 1935), organizations based on co-operatives but also linked to the state were supported, to encourage rational private cutting (Holopainen, 1957). The traumatic 1939-45 war left Finland with many refugees and a large bill for reparations payments: the refugees were settled, and the need to increase exports made private forestry even more important in the Finnish economy (Karjalainen, 1957).

But it was rapidly expanding industrial capacity between 1955 and 1965 which led to still greater efforts to reduce roundwood exports, utilize hardwoods and smaller wood, and, most important, to increase productivity through drainage, cultivation, and fertilization. Afforestation was also encouraged (Numminen, 1970; Jaatinen and Alalamuni, 1978). The TEHO and MERA plans of the 1960 s were designed to increase the allowable cut while promoting mechanization and maintaining prices stable (Christie, 1962; Holopainen, 1968; Kirves, 1966). Between 1965 and 1975 , over 4 billion (1975) markka - over $\$ 1$ billion - were invested in seeding, planting, thinning, fertilisation, drainage, and roads on private lands. Since $50 \%$ was invested by private owners themselves, their response to incentive grants was of great interest (Kuusela, 1979; Official Statistics of Finland, T1.7.3.). It was even more vital to the World Bank project which began in 1973 and which aimed to have improvements made on 60,000 farmer-owned forests, so that the allowable cut could be increased (International Bank, 1972).

Since the forest sector is basic to the Finnish economy, and since smallholders control so much of the forest, it is not surprising that programmes to encourage silvicultural investments have been accompanied by sophisticated studies of farmers' social characteristics, their attitudes towards silviculture, and their cutting behaviour.

\section{The Sociological Tradition}

It was Päiviö Riihinen, now Professor of the Social Economics of Forestry, who re-commenced in the 1960s the systematic study of farm woodlots begun by Osara. An early paper (Riihinen, 1963) examined the relationship of farm silviculture with both farm characteristics (e.g., size of woodlot, proportion of good site types on the land) and the socio-economic environment of the farm. This study used econometric techniques, but it also pioneered the use of factor analysis, which allows the simultaneous consideration of a large number of variables. (Like many innovations, this had been borrowed from abroad by the eclectic Finnish researchers; see Mignery, 1956.) Riihinen's study showed the importance of economic and social variables, both in themselves and in interaction with farm characteristics. In a later study (Riihinen, 1966), data on farm environments and characteristics were supplemented with interviews, and factor analysis was again used to sort out clusters of characteristics associated with high levels of forestry knowledge and silvicultural practice. It was found, for in- 
stance, that the level of forestry knowledge did not depend on the absolute size of forest owned so much as on the size of forest relative to arable. Further consideration showed that forest improvement and knowledge moved in a U-curve with industrialization: isolated, traditionalistic owners treated their forests with old, inefficient methods; with modernization and education, owners made improvements; but higher-income, newer owners neither knew the traditional ways nor were they positively inclined towards new methods (Riihinen, 1970)

In this research, given that the state was encouraging silvicultural investments, there was a clear link with the goal of increasing national forest productivity:

Our principal interest is in such characteristics of forest owners as are capable of providing forest policy instruments. (Riihinen, 1970, p5)

Obviously, such an approach does raise the problems of manipulation and paternalism, particularly when the experimental nature of applied forestry is recognised:

Negative attitudes are simply those regarded as such by professional foresters: attitudes not in agreement with our aims. (Riihinen, 1970, p11)

Nevertheless, this view is not much different from that of agricultural extension workers, who seek to persuade farmers to adopt new techniques and to make im. provements. In Finland, farmers' organizations are strong and centralized and fulfill many functions undertaken by Canadian state agencies, but the diffusion of information to farmers has been studied as in North America (VainoMattila, 1969; Westermarck, 1973). It was around this question that Järveläinen (1968) centred the first results of a study based on 289 interviews in two very different communes, Jämsä (isolated and traditional) and Karstula (industrializing). This study related farm characteristics, farm environments, and farmers' silvicultural knowledge and behaviour to contact with professionals and farm organizations. Later attitudinal studies by Järveläinen provided the framework for understanding - and influencing — farmers' behaviour more thoroughly (Justin, 1977)

It was Kauko Hahtola, now Professor of Land-Use Economics, who carried through the early thrust of viewing the farm as a whole operation. Small-forest management had to be seen in relation to a total model of farming (Hahtola, 1967a). Starting with a large number of farm variables, Hahtola analyzed them into 12 factors such as 'structure of labour input in cutting' and 'self-sufficiency in tractive power', each of which varied by region and had different effects on owners' cutting behaviour. Hahtola also (1967b) built factors upon which variables loaded differently into ideal types of farming styles: 'problem farms', for instance, were small, traditionally managed (often highgraded), and usually overcut; where industrialization was rapid, land-use competition increased and interest was distracted from the woodlot; 'family farming' had intensive management but low productivity (and offered the best opportunity for more rational production). Hahtola's work shows the problem of selecting variables without much theoretical guidance and then relying upon factor analysis (which depends largely on intuitive understanding) to make sense of results, a procedure resulting in empirical generalizations at best. Nevertheless, such generalizations can be very useful, as shown in a study which predicted more irregular and light cutting as farm ownership patterns changed (Hahtola, Järveläinen and Reunala, 1973). Other works by Hahtola $(1971,1973)$ have been of considerable theoretical interest.

The most comprehensive studies of the sociology of private forestry in Finland have been done by Järveläinen. His 1966 investigation of owners in Jämsä and Karstula supplied the material for his masterly 'Factors Influencing Silvicultural Activity' (1971a), which was explicitly linked with national policy goals:
The main goal of forest policy in Finland today is to secure sufficient timber production. Sufficient timber production means that an adequate and continuously increasing flow of raw materials for the forest industry, an important export industry in Finland, can be supplied by the country's forests. Since 65 per cent of the forests in Finland are privately owned.... and since the share of these forests in the timber production in the whole country is almost 80 per cent the problems of sufficiency and intensification of timber production are intimately connected with private forests. Attainment of forest policy objectives is therefore essentially dependent on what happens in private forestry, i.e. on the behaviour of the individual forest owners, whose decisions vitally affect the production of timber. (p10)

Järveläinen designed an extensive questionnaire to measure background variables (farm and farmer characteristics), attitudes, and activity. Each set was factoranalyzeci, and Järveläinen revealed himself more familiar than most sociologists with the advantages and pitfalls of this technique $(1971 a, p 36 ; 1971 b)$. When the intercorrelations of factor scores were analyzed, it was found that owners' attitudes (towards forestry laws and silviculture) had little effect on their tendency to use experts and make improvements, but that they were important, especially in a modernizing rural environment, in determining owners' readiness to act (after taking over a farm) as well as their intensity (improvements/ha) of silvicultural activity.

In a later study Järveläinen surveyed 997 owners, and had questionnaires administered to local forestry technicians as well. This allowed more precise conclusions about the causes of small holders making silvicultural improvements (1974), and also pinpointed differences in the opinions of owners and forestry experts (1977). This line of work is continuing with the development of a sample which will be both larger $(3,000)$ and permanent (Järveläinen, 1978). This will allow the study of change over time, and will provide a sensitive instrument for evaluating the efficiency of changes in forest policy, particularly in incentive structures.

\section{Current Research}

Finnish research is now proceeding in three broad areas. The first is the study of the organizations active in the promotion of private forestry. Some theoretical work has been done in this area (Rinkinen, 1968). But opinions about the organizations have also been surveyed, in the context of a continuing debate about structural reform (Järveläinen, 1975). And much effort has been devoted to studying the lower levels of the organizations, especially local cooperatives and the attitudinal obstacles to their formation (Mäkelä, 1971, 1974, 1976; Vesikallio, 1974).

A second concern is the changing farm population. Industrialization in Finland has meant that many farmers take off-farm work, thereby neglecting the woodlot, and that those inheriting farms or buying them as vacation homes have less interest in forest income (although they are also more inclined to take professional advice). These trends have been thoroughly studied in their implications for the allowable cut (Reunala and Tikkanen, 1972; Reunala, 1974). Their effects on the actual cut have also been studied, both generally (Seppälä, 1974) and in relation to the regional price of wood (Alho, 1975; Häkkilä, 1978).

The final, and most important, concern has been to evaluate the effectiveness of policies which encourage silvicultural investments. Here the Finns have built on an established tradition of sociological research, combining it with newer techniques of public policy analysis. The heavy 
state investments of the $1965-75$ period have drawn some criticism in Finland, for incentives to landowners are challenged by other social groups (Talman, 1978). Not only have the efficiency and equity of the MERA subsidies been questioned (Ervasti et al., 1970; Kuusela, 1979), but the whole structure of forest administration, like other sectors, also has become increasingly politicized (Heiskanen and Sinkkonen, 1974). So, forest research has turned to scrutinize the effectiveness of policy and especially of incentives. From Riihinen's early studies, there has been a shift from macro-sociology to micro-economics:

From the standpoint of forest policy planning, an essential aim of the studies of forest owners' behaviour is detection and quantification of the socio-economic factors affecting the propensity to invest and sell. (Tikkanen, 1976, p378)

One promising new approach is the use of causal modelling. Assuming that the complex of socio-economic, attitudinal, and behavioural variables can be related in causal terms, then the manipulable policy variables (grants and extension services) can be worked in as well, and their measurable impact compared with their cost (Tikkanen, 1978). Such model-building would be highly potent in combination with panel surveys like Järveläinen's.

\section{Conclusion}

In Finland, the forests underpin the economy, and smallholders are the most important factors in forest productivity. This has encouraged a tradition of research which combines sociology and economics and forestry, and which has had as its central question how to encourage productivity while maintaining freedom; that is, how to bring owners to want to make investments in their forests and to harvest them in a rhythym suited to industrial needs. In Canada, due to the size of Crown and large private holdings, these concerns have been less relevant. But now pressure on the forest resource is increasing, especially in the East, and smallholders are being called upon to manage their woodlots better. Experiments and new programmes in the Eastern Canadian provinces are underway now to achieve this end, and woodlot-owners' organizations and incentive grants are growing throughout the country. Canadian foresters certainly could give more adequate policy advice and evaluate policy effectiveness better by availing themselves of the Finnish tradition of forest sociology. Studies which borrowed from this established tradition, while fitting it to Canadian conditions, could serve us well.

\section{Acknowledgement}

I was fortunate to benefit from a study period in Finland in the autumn of 1979 , and I wish to thank my colleagues and friends in the Department of Social Economics of Forestry, University of Helsinki, as well as the Ministry of Education (Finland) and the Canadian-Scandinavian Foundation, for their help and support.

\section{References}

Alho, P. 1975. Regional differences in forest returns within Finland. Acta For. Fennia 158

Christie, J.M. 1962. Impressions of forestry in Finland. London: Forest. Comm. Res. Paper No. 25.

Darveau, Grenier, Lussier and Associates. 1978. Forest industry rationalization: a general approach and a pilot study. Prepared for the Federal/Provincial For. Indust. Development Committee.

Ervasti, S., Heikenheimo, L., Kuusela, K., and Mäkinen, V. 1970. Forestry and forest industry production alternatives in Finland, 1970-2015. Fol. For. 88

Hahtola, K. 1967a. Delivery cuts of timber in farm management. Acta For. Fenn. 84.1.

1967b. Farm forestry and its socio-economic environment. Acta For. Fenn. 84.2.
1971. Forest owner's decision making and theories of the firm. Tyotehoseuran Julkaisuja 158.

1973. Research approaches applied in the Finnish studies of forest owners' behaviour. Silva Fenn. 7: 236-54

Järveläinen, V.-P., and Reunala, A. 1973. The timber-sales behaviour of private forest owners. Silva Fenn. 7: 163-77.

Häkkilä, M. 1978. Forests and forest returns on Finnish farms. Nordia 12: 283-93

Heiskanen, I., and Sinkkonen, S. 1974. From legalism to information technology and politicization: the development of public administration in Finland. University of Helsinki. Inst. of Pol. Sci. Res. Rep. No. 31.

Holopainen, V. 1957. Promotion of private forestry in Finland: Tapio 1907-1957. Silva Fenn. 94: 7-322.

1968. The forest policy of independent Finland, in Central Association of Finnish Woodworking Industries. The forest industry in independent Finland. Helsinki: Finnish Paper and Timber Journal.

International Bank for Reconstruction and Development. 1972. Appraisal of forest improvement project Finland, report No. PA152a, 28 November 1972.

Jaatinen, S., and Alalamuni, P. 1978. The field-reservation scheme of Finland 1969-1977. Nordia 12: 13-30.

Järveläinen, V.-P. with Vadén, T. 1968. Professional insight and its diffusion within farm forestry. Silva Fenn. 2:211-24.

Järveläinen, V.-P. 1971a. Factors influencing silvicultural activity. Commun. Inst. For. Fenn. 73.2

1971b. Some aspects concerning the use of factor analysis. Silva Fenn. 5: 281-90.

1974. Forestry behaviour of private forest owners in Finland. Fol. For. 222

1975. Forestry experts' and appointed representatives' opinions about official forestry administration and its development in Finland. Silva Fenn. 9: 15-48.

1977. Opinions in Finnish private forestry. Fol. For. 334. 1978. Monitoring the development of Finnish private orestry: a test of an information system based on a sample of forest holdings. Fol. For. 354.

Jones, M. 1977. Land-tenure policies in Finland: aims and results in historical perspective. Scan. For. Econ. 15: 25-9.

Juslin, H. 1977. Influencing private forest owners' attitudes towards timber sales. Acta For. Fenn. 157.

Karjalainen, A. 1957. A national economy based on wood. Helsinki: Tammi.

Kirves, L. 1966. Some basic issues of the present phase of development of the Finnish forest industry. Kansallis-OsakePankki Economic Review 1966, 4: 175-82.

Kuusela, K. 1979. Experience gained of forest investments. Kansallis-Osake-Pankki Economic Review 1979, 2: 3-12.

Mäkelä, J. 1971. The opinions of Finnish forest owners about co-operation, and its occurrence. Työtehoseuran Julkaisuja 153.

1974. Variation in co-operation readiness of Finnish forest owners. Työte. Julk. 175

1976. New findings of the investigations concerning the co-operation of forest owners. Työte. Metsätiedotus 261

Marsh, R.E. 1954. Public policy toward private forest land in Sweden, Norway, and Finland. Washington: Charles Lathrop Pack For. Found.

Mignery, A.L. 1956. Factors affecting small-woodland management in Nacogdoches County, Texas. J. of For. 54: 102-5.

Numminen, J. 1970. Afforestation of agricultural land under soil bank contracts. Silva Fenn. 4: 245-61.

Official Statistics of Finland. 1979. Yearbook of forest statistics 1977-1978. Helsinki: The Finn. Forest Res. Instit. (Also Fol. For. 375.)

Osara, N. 1935. Suomen pienmetsatalous. Comm. Inst. For. Fenn. 21.1

Reunala, A. 1974. Structural change of private forest ownership in Finland. Comm. Inst. For. Fenn. 82.3.

Reunala, A., and Tikkanen, I. 1972. Non-farmer forest owners and promotion of private forestry. Fol. For. 134.

Riihinen, P. 1963. Variations in the level of silviculture on the Finnish farm woodlots. Acta For. Fenn. 75.6.

1966. Economic and social behaviour of forest-owners in Ostrobothnia. Metsätaloudellinen Aikakauslehti 83.11.

1970. The forest owner and his attitudes toward forestry promotion. Acta For. Fenn. 109.

Rinkinen, I. 1968. Development alternatives in the organization 
chains of Finnish forestry. Silva Fenn. 2: 25-48.

Senior Forestry Officials (ad hoc Steering Committee). 1979 Forestry imperatives for Canada: a proposal for forest policy in Canada, prepared for the Canadian Council of Resource and Environment Ministers, May 1979.

Seppälä, R. 1974. Cutting behaviour of private forest owners in eastern Finland. Fol. For. 189.

Siuruainen, E. 1978. On the history of rural settlement in Finland. Nordia 12: 67-77.

Talman, P. 1978. Government aid to private enterprise in Finland. Nordia 12: 37-51.

Tikkanen, I. 1976. Effectiveness of forest policy measures as applied to small woodlands: conceptual and methodological background, in XVI IUFRO World Congress. Proc. Div. IV: 376-85.

1978. Methodologies for analyzing forest policy effects: a case study with an application of path analysis, prepared for IUFRO Working Party 4.06.01, meeting of May 27-29 1978.

Vaino-Mattila, I. 1969. Extension services as a source of farming information. Helsinki: Publications of the Marketing Research Institute of Pellervo Society, No. 11.

Vesikallio, H. 1974. Rationalization of forest work through regional co-operation in private forestry. University of Helsinki, Dept. of Social Econ. of For. Res. Rep. No. 2.

Westermarck, H. 1973. Peer farmers' role in the adoption of recommended practices. Acta Agralia Fenn. 129.
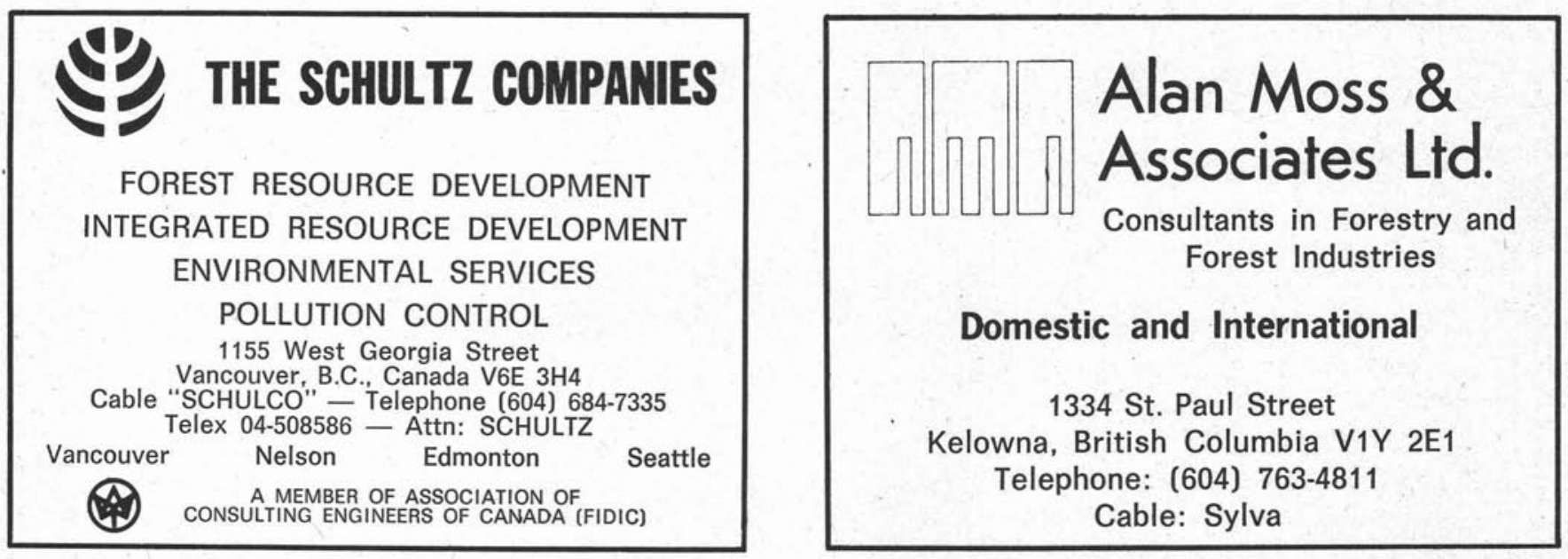

\section{Plus de $\$ 101 / 2$ millions d'assurance!}

Près de 400 membres de l'Institut Forestier du Canada, ainsi que leurs familles, ont trouvé la solution à la plupart de leurs exigences d'assurance-vie. Ils ont saisi l'occasion de souscrire au programme d'assurance-vie de l'Institut Forestier du Canada, que L'Impériale administre au nom de I'Institut. L'assurance s'élève à plus de $\$ 10 \quad \frac{1}{2}$ millions (incluant le boni de $50 \%$ payable sur toutes les réclamations jusqu'au 30 avril 1981 au moins).

Qu'en pensez-vous? Êtes-vous inscrit au régime? Si vous avez 50 ans ou moins, vous pouvez être assuré pour une somme de $\$ 100,000$, avec des taux très bas. Jusqu'à l'âge de 30 ans, le coût d'assurance est de $\$ 2.00$ par $\$ 1,000$ annuellement et, de l'âge de 31 à 40 ans, il est de $\$ 2.80$ par $\$ 1,000$ d'assurance.

Si vous avez déjà souscrit cette assurance, vous devriez peut-être penser à augmenter votre assurance afin de faire face aux imprévus et à la cherté de la vie. Pensez-y et contactez l'Institut, sans aucune obligation, si vous avez besoin de plus amples renseignements. L'adresse est B.P. 5000 , Collège Macdonald, Québec H9X $1 \mathrm{C} 0$. 